\title{
Crystallization, habit modification and control of nucleation of glycine polymorphs from aqueous solutions doped with magnesium sulfate impurity
}

\author{
S. Anbu Chudar Azhagan ${ }^{1 *}$, V.S. Kathiravan ${ }^{1}$, N. SAthiya Priya ${ }^{2}$ \\ ${ }^{1}$ Department of Physics, Government College of Technology, Coimbatore-641013, India \\ ${ }^{2}$ Department of Physics, Nehru Institute of Technology, Coimbatore-641105, India
}

\begin{abstract}
The influence of magnesium sulfate as an additive in the nucleation of $\alpha$ and $\gamma$-polymorphs of glycine crystallized from aqueous solutions has been explored for the first time. Based on crystallization experiments, it was concluded that lower concentration of magnesium sulfate, say less than $2 \mathrm{~g} / \mathrm{mL}$, favors $\alpha$-nucleation sites, whereas the optimized concentration of magnesium sulfate impurity to yield $\gamma$-nucleation sites is $2 \mathrm{~g} / \mathrm{mL}$ and above. The nucleation time span (in days), solubility and $\mathrm{pH}$ were measured for $\alpha$ - and $\gamma$-nucleation sites in the aqueous solutions doped with magnesium sulfate. The glycine polymorphs $\alpha$ - and $\gamma$-single crystals were grown by slow solvent evaporation technique at ambient temperature. Crystal habit of glycine polymorphs was investigated and analyzed using goniometry. The unit cell dimensions and space group of the as-grown crystal were identified by single crystal XRD analysis. Both $\alpha$ - and $\gamma$-polymorphs of glycine were characterized structurally by powder XRD studies. The percentage of magnesium present in the grown glycine crystals was estimated by inductively coupled plasma optical emission spectrometry elemental analysis (ICP-OES). The nonlinear optical properties of the $\gamma$-glycine crystals were examined by Q-switched high energy Nd:YAG laser. The second harmonic generation output efficiency of the as-grown gamma glycine single crystals was computed to be 1.31 times superior than that of the reference material potassium dihydrogen phosphate (KDP).
\end{abstract}

Keywords: crystal morphology; X-ray diffraction; single crystal growth; nucleation; solubility; solvents

\section{Introduction}

In recent times, more and more attention has been given to control crystallization from solutions because this process is important for preparation and purification of pharmaceuticals and other industrial chemicals [1,2]. Currently, amino acid glycine is capable of forming six different polymorphic forms namely $\alpha, \beta$ and $\gamma$ at ambient conditions and $\delta, \epsilon$ and $\beta^{1}$ forms at high pressure conditions [3-9]. The thermodynamically most stable form of glycine polymorphs is $\gamma$-form which is considered as a potential candidate for piezoelectric, electrooptical, nonlinear optical and photonics applications. Polymorphism of glycine crystals in the presence of various additives has been reported by several authors in the recent past. $\gamma$-glycine was reported to form in acidic or basic solutions

*E-mail: anbuchudarazhagan@gmail.com or in solutions with addition of electrolytes or in the presence of tailor-made additives or other inorganic impurities/additives. $\gamma$-glycine was reported to become visible, when supersaturation generation is very slow, such as controlled evaporation of solvents $[10-29,34]$. The investigation of polymorphism in pharmaceuticals has attracted an interest of scientific community because of its technological applications. In some cases, the additives are designed intentionally and added to study crystal morphology or to crystallize a stable polymorph or to control the solution-mediated phase transformation. The designed additives are often referred to as tailor-made additives. These additives or impurities operate as stereospecific nucleation inhibitors and affect the nucleation and crystal growth kinetics. The growth of crystal surfaces can be prevented or inhibited or promoted by the adsorption of tailor-made impurity molecules. The growth rate of crystal face may be affected by the degree 
of supersaturation, change in $\mathrm{pH}$ value, nature and concentration of additives and operating temperature. Tailor-made additives act as inhibitors and promoters of selective polymorph. Tailor-made additives can affect the crystal growth rate by adsorbing on specific crystal faces or crystal surfaces and they could influence the interfacial tension between the nuclei of crystal and the supersaturated solution. In certain situation, tailor-made impurity alters the solution thermodynamics, such as solubility and $\mathrm{pH}[1,2,34]$. The present research work focuses on crystallization of $\gamma$-polymorph of glycine from aqueous solutions containing tailor-made impurity magnesium sulfate heptahydrate as additive. The tailor-made additive magnesium sulfate heptahydrate acts as stereospecific nucleation inhibitor in glycine saturated solutions. The stereoselectivity of this additive determines the favorable adsorption sites in supersaturated glycine solutions. The association between the solubility of $\alpha$ - and $\gamma$-polymorphs in magnesium sulfate heptahydrate solution $\left(\mathrm{MgSO}_{4} \cdot 7 \mathrm{H}_{2} \mathrm{O}\right)$ is elucidated by solubility diagram. The additive magnesium sulfate heptahydrate causes an adsorption on the crystal facets, or on specific crystal facets which alters the surface free energy and may block the active growth sites on the embryonic nucleus surface and inhibit its critical size, which is essential for incorporation of solute into the crystal lattice. The final outcome is kinetic and morphological changes in glycine polymorphs. Magnesium sulfate heptahydrate salt is a slightly acidic fast drying agent, hygroscopic in its anhydrous form, hydrophilic additive. When it is exposed to water it forms hydrate having the general formula $\mathrm{MgSO}_{4} \cdot 7 \mathrm{H}_{2} \mathrm{O}$. It is interesting to note that the magnesium sulfate species inclusion changes the solubility and $\mathrm{pH}$ of glycine saturated solutions in double distilled water.

\section{Experimental}

A series of glycine solutions were prepared from a consumable glycine salt $\left(\mathrm{C}_{2} \mathrm{H}_{5} \mathrm{NO}_{2}\right.$ aminoacetic acid with molecular weight of $75.07 \mathrm{~g} / \mathrm{mol}$ purchased from Qualigens, AR grade of $99.9 \%$ purity) and selected additive magnesium sulfate heptahydrate salt $\left(\mathrm{MgSO}_{4} \cdot 7 \mathrm{H}_{2} \mathrm{O}\right.$ with molecular weight of $246.47 \mathrm{~g} / \mathrm{mol}$ purchased from Merck, AR grade of $99.9 \%$ purity) with the weights ranging from $1 \mathrm{~g} / \mathrm{mL}$ to $10 \mathrm{~g} / \mathrm{mL}$. Glycine solutions were prepared at room temperature by adding the magnesium sulfate salt and mixing each in steps of $1 \mathrm{~g} / \mathrm{mL}$ up to $10 \mathrm{~g} / \mathrm{mL}$, respectively, in $100 \mathrm{~mL}$ of double distilled water in separate but similar crystallization beakers. In these magnesium sulfate heptahydrate solutions $\left(\mathrm{MgSO}_{4} \cdot 7 \mathrm{H}_{2} \mathrm{O}\right)$, the required amounts of glycine salt were added and the solutions were stirred continuously for about $6 \mathrm{~h}$ with Remi make magnetic stirrer at the stirring rate of 380 RPM. The saturation of glycine solutions was confirmed by deposition of undissolved salt in the crystallization beakers. The saturated glycine solutions were filtered through a 41 grade Whatman filter paper of porosity $20 \mu \mathrm{m}$, into crystallization dishes which were then covered with perforated polythene sheets for slow solvent evaporation. The filtered saturated glycine solutions were collected in crystallization dishes of the size $100 \mathrm{~mm} \times 50 \mathrm{~mm}$ and were kept in a dust-free, vibration-free compartment to yield well shaped crystals. The ten solution combinations of saturated glycine solutions became supersaturated after a nucleation time span of 14 days to 5 days, respectively. Fig. 1 shows the graph of nucleation time span versus concentration of magnesium sulfate as impurity salt. The nucleation time span and other details for the grown glycine crystals are elucidated in Table 1. From Table 1, it is obvious that higher concentration of magnesium sulfate as impurity salt stimulates quick nucleation sites.

\subsection{Solubility and $\mathrm{pH}$ measurement of glycine polymorphs}

Polymorph crystallization is controlled by two factors, primary and secondary. Supersaturation, temperature, seed crystals, stirring rate are the primary factors controlling crystallization of polymorphs. $\mathrm{pH}$, solvent, additives, solubility based crystallization are the secondary factors connected to the external substances. A polymorph of a substance exhibits different solubility and the solubility of metastable form is always higher when it is compared to that of the most stable form. 
Table 1. Nucleation time span and other details.

\begin{tabular}{|c|c|c|c|c|}
\hline \multirow[t]{2}{*}{$\begin{array}{l}\text { Concentration of } \\
\text { magnesium sulfate } \\
\text { additive added into } \\
\text { glycine solutions } \\
\text { [g/100 mL DD water] }\end{array}$} & \multirow[t]{2}{*}{$\begin{array}{c}\text { Stirring rate } \\
\text { [RPM] }\end{array}$} & $\begin{array}{l}\text { Nucleation sites } \\
\text { observed after } \\
\text { supersaturation } \\
\text { [in days] }\end{array}$ & $\begin{array}{l}\text { Behavior of crystal } \\
\text { growth }\end{array}$ & $\begin{array}{l}\text { Confirmation of polymorph by } \\
\text { PXRD and SXRD studies }\end{array}$ \\
\hline & & No. of days & Behavior & Polymorph \\
\hline 1 & \multirow{7}{*}{380 RPM } & 14 & prismatic morphology & $\alpha$ \\
\hline 2 & & 9 & unidirectional growth & $\gamma$ \\
\hline 3 & & 9 & unidirectional growth & $\gamma$ \\
\hline 4 & & 8 & unidirectional growth & $\gamma$ \\
\hline 5 & & 8 & unidirectional growth & $\gamma$ \\
\hline 6 & & 7 & unidirectional growth & $\gamma$ \\
\hline 7 & & 6 & $\begin{array}{l}\text { unidirectional growth, } \\
\text { few clustered crystals }\end{array}$ & $\gamma$ \\
\hline 8 & & 6 & $\begin{array}{c}\text { unidirectional growth, } \\
\text { twinned secondary } \\
\text { crystals }\end{array}$ & $\gamma$ \\
\hline 9 & & 5 & unidirectional growth & $\gamma$ \\
\hline 10 & & 5 & unidirectional growth & $\gamma$ \\
\hline
\end{tabular}

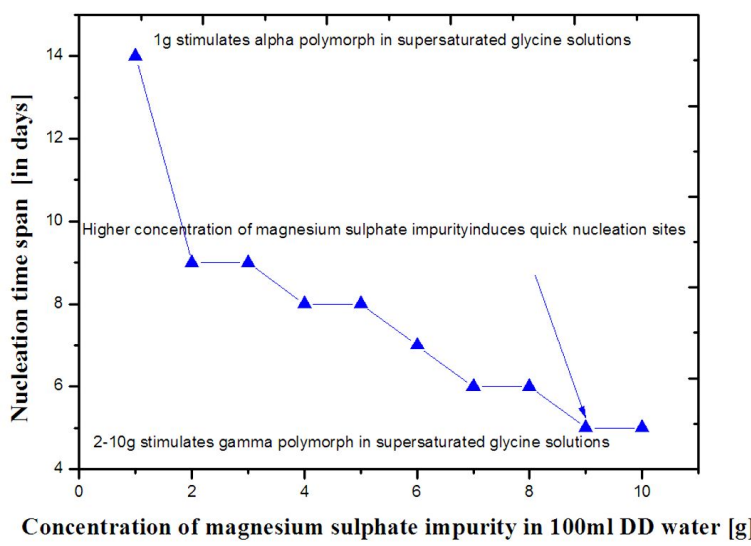

Fig. 1. Nucleation time span versus magnesium sulfate concentration.

The relative thermodynamic stability of glycine polymorphs and the direction of polymorphic transformation can be studied from the solubility of the polymorphs. The solubility of the chemical substance in a given solvent is related to supersaturation of each polymorph and it is considered as a key aspect for polymorph control.
Several researchers [22-29] reported that the growth rate of a crystal strongly depends on solubility and operating temperature. Solubility was determined for both $\alpha$ - and $\gamma$-glycine in water by gravimetric method. The solubility versus temperature plots for the samples of $\alpha$ - and $\gamma$-glycine crystals are shown in Fig. 2. It is explicit from the solubility curves that the solubility of $\alpha$-form of glycine is higher than that of $\gamma$-form of glycine. This end result elucidates that gamma polymorph of glycine is a stable and less water soluble form at ambient temperature. The order of the thermodynamic stability of the glycine polymorphs at ambient temperature was found to be $\gamma>\alpha$ [23-25]. In a similar fashion, the solubility of two polymorphs of glycine, $\alpha$ - and $\gamma$-glycine was calculated in magnesium sulfate heptahydrate solution $\mathrm{MgSO}_{4} \cdot 7 \mathrm{H}_{2} \mathrm{O}$ with magnesium sulfate concentration of $3 \mathrm{~g} / \mathrm{mL}$, and the solubility curves are presented in Fig. 3. The solubility of both polymorphs is increased with inclusion of magnesium sulfate species in the solution. Further, it is evident from Fig. 3 that the solubility of $\gamma$-glycine is increased 


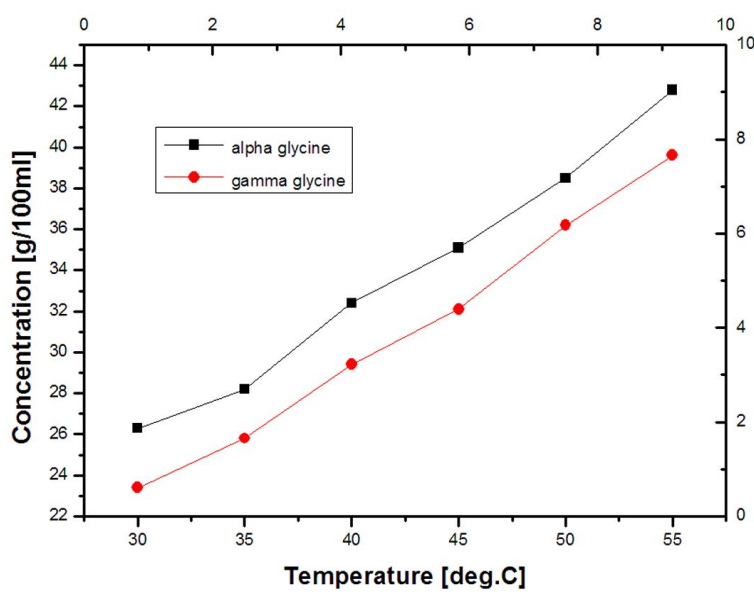

Fig. 2. Solubility of glycine polymorphs in double distilled water.

more than that of the $\alpha$-form in magnesium sulfate heptahydrate solution $\mathrm{MgSO}_{4} \cdot 7 \mathrm{H}_{2} \mathrm{O}$ with magnesium sulfate concentration of $3 \mathrm{~g} / \mathrm{mL}$. The next step was to measure solubility of $\gamma$-glycine at various concentrations of magnesium sulfate $(1-10 \mathrm{~g} / \mathrm{mL}$ increased in steps of $1 \mathrm{~g} / \mathrm{mL}$ ). The plotted graph of glycine solubility versus magnesium sulfate concentration proved that the solubility of $\gamma$-form of glycine increases more with an increase in magnesium sulfate concentration and it is shown in Fig. 4. The $\mathrm{pH}$ values were measured for glycine polymorphs in magnesium sulfate solution with various concentrations. Fig. 5 shows the $\mathrm{pH}$ profile curve of glycine solution versus magnesium sulfate concentration. It is apparent that the $\mathrm{pH}$ values decrease with an increase in magnesium sulfate concentration.

\subsection{Crystal morphology of $\alpha-$ and $\gamma$-glycine}

The morphologies of glycine polymorphs observed in magnesium sulfate heptahydrate $\mathrm{MgSO}_{4} \cdot 7 \mathrm{H}_{2} \mathrm{O}$ environment with concentrations of $1 \mathrm{~g} / \mathrm{mL}$ and $3 \mathrm{~g} / \mathrm{mL}$, respectively, are presented in Fig. 6 and Fig. 7 for comparison. Fig. 6a shows the bipyramidal shape morphology of $\alpha$-glycine crystal obtained in magnesium sulfate with a concentration of $1 \mathrm{~g} / \mathrm{mL}$ and its schematic drawing displaying crystal planes, such

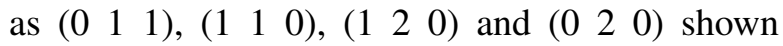

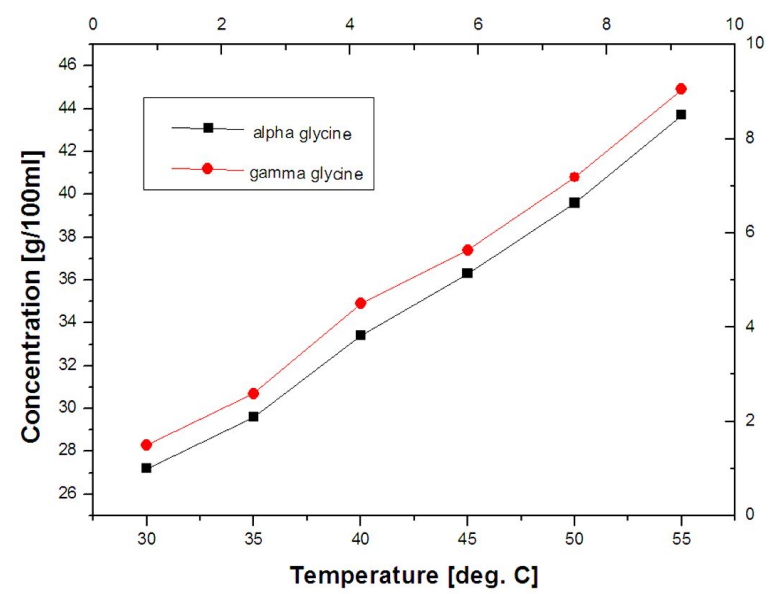

Fig. 3. Solubility curve of $\alpha$ - and $\gamma$-glycine in magnesium sulfate solution.

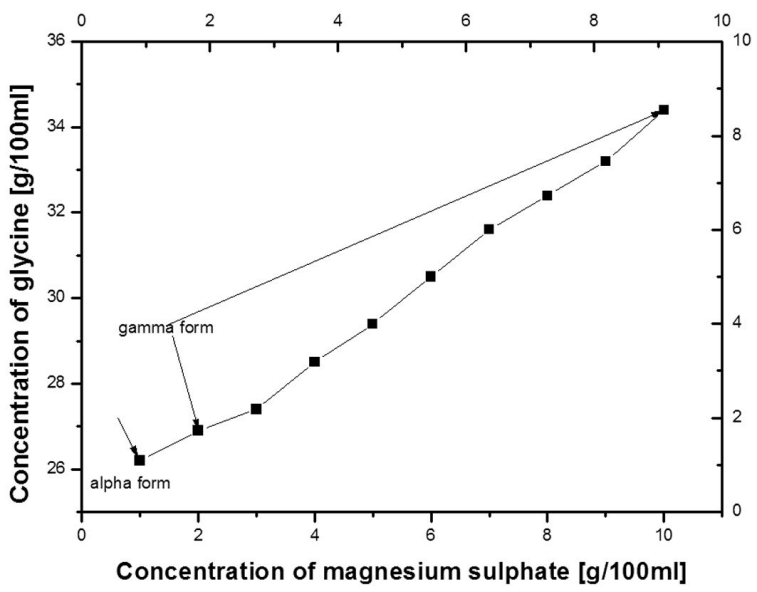

Fig. 4. Solubility of glycine versus various concentrations of magnesium sulfate.

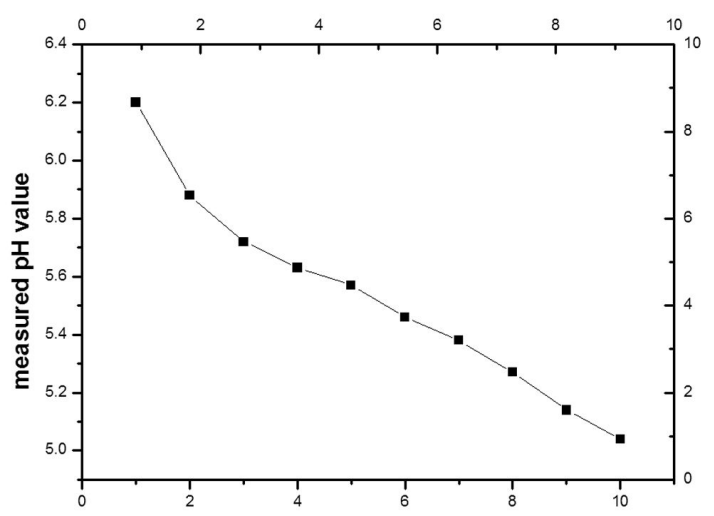

Concentration of magnesium sulphate $[\mathrm{g} / 100 \mathrm{ml}]$ in glycine solutions

Fig. 5. $\mathrm{pH}$ variation in glycine solution versus various concentrations of magnesium sulfate. 
in Fig. 6b. The bipyramidal shaped $\alpha$-glycine crystal planes were drawn and indexed with the aid of literature data by Bisker-Leib et al. [35]. Fig. $6 \mathrm{~b}$ depicts the morphology of $\alpha$-glycine single crystal which is very similar to the crystal morphology reported by Bisker-Leib et al. [35]. To confirm the $\alpha$-polymorphic form of glycine, $\mathrm{X}$-ray powder diffraction analysis was made. The signature peaks of $\alpha$-glycine in the X-ray diffractogram reveal that the grown crystal is of $\alpha$-form of glycine which is discussed thoroughly in the result and discussion section. Fig. 7a displays the trigonal pyramidal shape of $\gamma$-glycine crystal obtained in magnesium sulfate with a concentration of $3 \mathrm{~g} / \mathrm{mL}$ and its schematic drawing showing well developed crystal planes ( $\left.\begin{array}{lll}1 & 0 & 1\end{array}\right),\left(\begin{array}{lll}0 & \overline{1} & 1\end{array}\right)$ and $\left(\begin{array}{lll}\overline{1} & 1 & 1\end{array}\right)$ shown in Fig. 7b. Trigonal pyramidal shape of $\gamma$-glycine crystal planes was drawn and indexed with the aid of SMORF crystal morphology software and the literature data $[12,25]$. The $\gamma$-polymorphic form of glycine was confirmed by both powder XRD and single crystal XRD results.

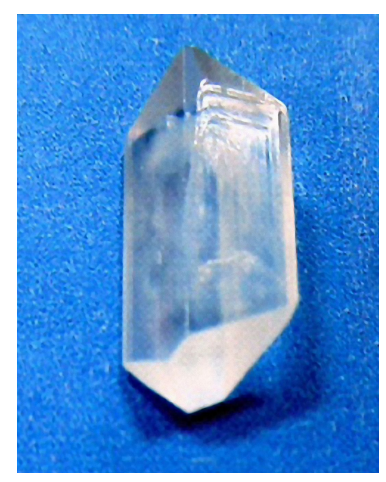

(a)

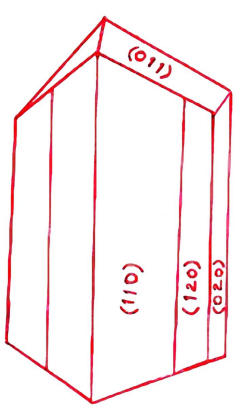

(b)
Fig. 6. (a) $\alpha$-glycine single crystal; (b) $\alpha$-glycine crystal morphology.

\section{Results and discussion}

Towler et al. [33] reported that $\gamma$-form of glycine forms at low and high $\mathrm{pH}$ aqueous solutions. But in the present work, $\gamma$-form of glycine was obtained at low $\mathrm{pH}$ $\mathrm{MgSO}_{4}$ solutions. $\alpha$-glycine forms at $\mathrm{pH}$ close to the isoelectric point. The effect of shifting

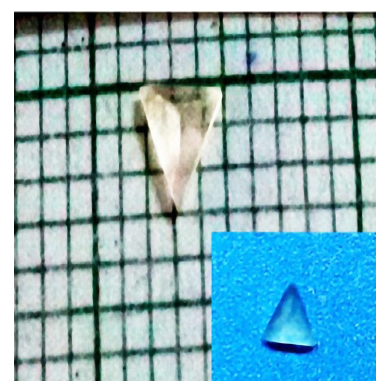

(a)

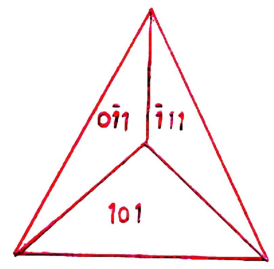

(b)
Fig. 7. (a) $\gamma$-glycine single crystal; (b) $\gamma$-glycine crystal morphology.

the $\mathrm{pH}$ beyond the isoelectric point manifests itself in reducing the cyclic dimers and increase in the content of monomeric zwitterions to form the polar chain structure of the $\gamma$-polymorph [32-34]. Towler et al. [33] reported that the dissimilarity of nucleation type at different $\mathrm{pH}$ levels results from the presence of growth species of different nature for crystallization in the solution medium. Amino acid glycine molecules mostly exist as zwitterionic cyclic dimers which usually crystallize in $\alpha$-form of glycine in aqueous solutions. In addition, the highly dimerized zwitterionic glycine solution, around the isoelectric point of glycine $(\mathrm{pH}=5.97)$ induces the nucleation of $\alpha$-polymorph. When the $\mathrm{pH}$ is altered, the increasing concentration of charged glycine species is produced in the solution which induces the nucleation of both metastable $\alpha$-polymorph and stable $\gamma$-polymorph. When the glycine dissolves in water, the zwitterion interacts with water molecules acting as both an acid and a base. If $\mathrm{pH}$ is decreased by adding an acid to a solution of amino acid containing glycine, the -COO- part of the zwitterion picks up a hydrogen ion. Towler et al. [33] concluded from the $\mathrm{pH}$ studies that the $\gamma$-polymorph is nucleated at lower $(\mathrm{pH}<3.8)$ and higher $(\mathrm{pH}>8.9)$ values of the $\mathrm{pH}$ in the solution. In the literature, it is agreed that a water solution of magnesium sulfate is slightly acidic in nature. The $\mathrm{pH}$ of an aqueous magnesium sulfate solution is related to the molarity of the magnesium sulfate. Normally, the $\mathrm{pH}$ is between 5.5 and 6.5 due to magnesium affinity for hydroxide ion $\left(\mathrm{OH}^{-}\right)$. When the sulfate enters the solution, hydroxide anions connected 
Table 2. Lattice parameters from indexed powder XRD computed by Unit Cell Software Package.

\begin{tabular}{|c|c|c|c|c|c|c|c|c|}
\hline \multirow[t]{2}{*}{ Sample name } & \multicolumn{5}{|c|}{$\begin{array}{l}\text { Computed lattice parameters } \\
\text { from unit cell software } \\
\text { package }\end{array}$} & \multirow[t]{2}{*}{$\begin{array}{l}\text { Crystal } \\
\text { structure }\end{array}$} & \multirow{2}{*}{$\begin{array}{c}\text { Matches with } \\
\text { JCPDS [30] } \\
\text { crystal } \\
\text { data ID } \\
\end{array}$} & \multirow{2}{*}{$\begin{array}{c}\text { Presence } \\
\text { of } \mathrm{Mg} \\
\text { element } \\
\text { in }[\%] \\
\end{array}$} \\
\hline & $\mathrm{a}[\AA]$ & $\mathrm{b}[\AA]$ & $\mathrm{c}[\AA]$ & $\mathrm{V}\left[\AA^{3}\right]$ & Interfacial angles & & & \\
\hline $1 \mathrm{~g} / \mathrm{mL} \mathrm{MgSO}_{4}$ & 5.516 & 12.021 & 5.169 & 316.89 & $\beta=112.43^{\circ}$ & & $32-1702$ & 0.024 \\
\hline $\begin{array}{l}\text { glycine }+ \\
2 \mathrm{~g} / \mathrm{mL} \mathrm{MgSO}_{4}\end{array}$ & 7.071 & 7.071 & 5.494 & 237.94 & $\alpha=\beta=90^{\circ} \gamma=120^{\circ}$ & xagonal & 06-0230 & 0.067 \\
\hline $\begin{array}{l}\text { glycine }+ \\
3 \mathrm{~g} / \mathrm{mL} \mathrm{MgSO}_{4}\end{array}$ & 7.057 & 7.057 & 5.501 & 237.33 & $\alpha=\beta=90^{\circ} \gamma=120^{\circ}$ & exagonal & 06-0230 & .046 \\
\hline $\begin{array}{l}\text { glycine }+ \\
4 \mathrm{~g} / \mathrm{mL} \mathrm{MgSO}_{4}\end{array}$ & 7.046 & 7.046 & 5.479 & 235.64 & $\alpha=\beta=90^{\circ} \gamma=$ & & $06-0230$ & 0.038 \\
\hline $\begin{array}{l}\text { glycine }+ \\
5 \mathrm{~g} / \mathrm{mL} \mathrm{MgSO}_{4}\end{array}$ & 7.092 & 7.092 & 5.506 & 239.85 & $\alpha=\beta=90^{\circ} \gamma=$ & & $06-0230$ & 0.035 \\
\hline $\begin{array}{l}\text { glycine }+ \\
6 \mathrm{~g} / \mathrm{mL} \mathrm{MgSO}_{4}\end{array}$ & 7.077 & 7.077 & 5.51 & 239.07 & $\alpha=\beta=90^{\circ} \gamma=120^{\circ}$ & hexag & $06-0230$ & 0.154 \\
\hline $\begin{array}{l}\text { glycine }+ \\
7 \mathrm{~g} / \mathrm{mL} \mathrm{MgSO}_{4}\end{array}$ & 7.087 & 7.087 & 5.513 & 239.86 & $\alpha=\beta=90^{\circ} \gamma=120^{\circ}$ & hexagonal & $06-0230$ & 0.081 \\
\hline $\begin{array}{l}\text { glycine }+ \\
\mathrm{g} / \mathrm{mL} \mathrm{MgSO}_{4}\end{array}$ & 7.081 & 7.081 & 5.510 & 239.28 & $\alpha=\beta=90^{\circ} \gamma=120^{\circ}$ & hexagonal & 06-0230 & 0.064 \\
\hline
\end{tabular}

with magnesium increase the relative ratio of $\mathrm{H}^{+}$ to $\mathrm{OH}^{-}$. Magnesium sulfate is very soluble in water. When dissolved in water, magnesium sulfate separates into magnesium $\left(\mathrm{Mg}^{2+}\right)$ ions, and sulfate $\left(\mathrm{SO}_{4}^{2-}\right)$ ions. Solutions of magnesium sulfate have a neutral $\mathrm{pH}$. On contrary to Towler et al. [33], $\mathrm{pH}$ values range was different in the present investigation; the addition of magnesium sulfate in the amount of $1 \mathrm{~g} / \mathrm{mL}$ into glycine solutions with $\mathrm{pH}$ value of 6.20 , yielded only $\alpha$-nucleation, whereas, the glycine solutions with magnesium sulfate concentration of $2 \mathrm{~g} / \mathrm{mL}$ and above with $\mathrm{pH}$ value ranging from 5.88 to 5.04 induced only $\gamma$-nucleation. The nucleation period of $\alpha$ - and $\gamma$-form of glycine is presented in Fig. 1. It clearly explains that both $\alpha$-and $\gamma$-nucleation occur in the solution only at lower supersaturation conditions and at higher supersaturation conditions, respectively. Further, the lower concentration of additive magnesium sulfate provides nucleation sites after long time span whereas the higher concentration of additive magnesium sulfate provides nucleation sites within a short interval of time. This confirms that $\gamma$-form of glycine nucleates more quickly than that of $\alpha$-form. During the crystallization experiment, inclusion of lower concentration of magnesium sulfate, say less than $2 \mathrm{~g} / \mathrm{mL}$, in the glycine solutions or $\mathrm{pH}$ changes in the solution linked with it, have not modified the crystal habit of the $\alpha$-form of glycine noticeably. The cause for this can be the nonpolar nature of the crystal morphology and zwitterionic glycine dimers packed in centrosymmetric (space group $\mathrm{P} 2_{1} / \mathrm{n}$ ) arrangement. The prismatic bipyramidal shaped $\alpha$-form of glycine crystal shows well-developed crystal planes such as ( $\left(\begin{array}{lll}0 & 1 & 1\end{array}\right),\left(\begin{array}{lll}1 & 1 & 0\end{array}\right),\left(\begin{array}{lll}1 & 2 & 0\end{array}\right)$ and $\left(\begin{array}{lll}0 & 2 & 0\end{array}\right)$. Among these crystal planes, the $\left(\begin{array}{lll}0 & 1 & 1\end{array}\right)$ faces are fast growing which results in a crystal morphology that is lengthened more along the c-axis than a-axis [7, 34]. When the concentration of additive magnesium sulfate is increased beyond the critical concentration $\geqslant 2 \mathrm{~g} / \mathrm{mL}$ to upper limit concentration of $10 \mathrm{~g} / \mathrm{mL}$ increasing in steps of $1 \mathrm{~g} / \mathrm{mL}$ and its corresponding $\mathrm{pH}$ range is of $5.04>\mathrm{pH}<5.88$, respectively, the additive magnesium sulfate affects the growth rate of crystal facets through inclusion into the crystal lattice, thereby, disturbing the crystal molecular arrangement and inducing most preferably $\gamma$-nucleation. Moreover, the additive molecule $\mathrm{MgSO}_{4}$ undergoes hydration during 
Table 3. Shift in $100 \%$ peak position due to addition of magnesium sulfate as impurity salt.

\begin{tabular}{|c|c|c|c|c|c|c|c|c|c|c|c|c|}
\hline \multirow[t]{2}{*}{ Sample name } & \multicolumn{4}{|c|}{$\begin{array}{l}\text { Lattice parameters computed } \\
\text { by unit cell software package }\end{array}$} & \multicolumn{4}{|c|}{$\begin{array}{l}\text { Lattice parameters from } \\
\text { JCPDS [30] }\end{array}$} & \multicolumn{4}{|c|}{$\begin{array}{l}\text { Variation in lattice } \\
\text { parameters due to } \\
\text { incorporation of } \\
\text { magnesium species in the } \\
\text { crystal lattice }\end{array}$} \\
\hline & $\mathrm{a}[\AA]$ & $\mathrm{b}[\AA]$ & $\mathrm{c}[\AA]$ & $\mathrm{V}\left[\AA^{3}\right]$ & $\mathrm{a}[\AA]$ & $\mathrm{b}[\AA]$ & $\mathrm{c}[\AA]$ & $\mathrm{V}\left[\AA^{3}\right]$ & $\mathrm{a}[\AA]$ & $\mathrm{b}[\AA]$ & $\mathrm{c}[\AA]$ & $\mathrm{V}\left[\AA^{3}\right]$ \\
\hline $\begin{array}{l}\text { glycine }+ \\
1 \mathrm{~g} / \mathrm{mL} \mathrm{MgSO}_{4}\end{array}$ & 5.516 & 12.021 & 5.169 & 316.89 & 5.462 & 11.96 & 5.107 & 310.14 & 0.054 & 0.061 & 0.062 & 6.75 \\
\hline $\begin{array}{l}\text { glycine }+ \\
2 \mathrm{~g} / \mathrm{mL} \mathrm{MgSO}_{4}\end{array}$ & 7.071 & 7.071 & 5.494 & 237.94 & 7.024 & 7.024 & 5.472 & 233.8 & 0.047 & 0.047 & 0.022 & 4.14 \\
\hline $\begin{array}{l}\text { glycine }+ \\
3 \mathrm{~g} / \mathrm{mL} \mathrm{MgSO}_{4}\end{array}$ & 7.057 & 7.057 & 5.501 & 237.33 & 7.024 & 7.024 & 5.472 & 233.8 & 0.033 & 0.033 & 0.029 & 3.53 \\
\hline $\begin{array}{l}\text { glycine }+ \\
4 \mathrm{~g} / \mathrm{mL} \mathrm{MgSO}_{4}\end{array}$ & 7.046 & 7.046 & 5.479 & 235.64 & 7.024 & 7.024 & 5.472 & 233.8 & 0.022 & 0.022 & 0.007 & 1.84 \\
\hline $\begin{array}{l}\text { glycine }+ \\
5 \mathrm{~g} / \mathrm{mL} \mathrm{MgSO}_{4}\end{array}$ & 7.092 & 7.092 & 5.506 & 239.85 & 7.024 & 7.024 & 5.472 & 233.8 & 0.068 & 0.068 & 0.034 & 6.05 \\
\hline $\begin{array}{l}\text { glycine }+ \\
6 \mathrm{~g} / \mathrm{mL} \mathrm{MgSO}_{4}\end{array}$ & 7.077 & 7.077 & 5.51 & 239.07 & 7.024 & 7.024 & 5.472 & 233.8 & 0.053 & 0.053 & 0.038 & 5.27 \\
\hline $\begin{array}{l}\text { glycine }+ \\
7 \mathrm{~g} / \mathrm{mL} \mathrm{MgSO}_{4}\end{array}$ & 7.087 & 7.087 & 5.513 & 239.86 & 7.024 & 7.024 & 5.472 & 233.8 & 0.063 & 0.063 & 0.041 & 6.06 \\
\hline $\begin{array}{l}\text { glycine }+ \\
8 \mathrm{~g} / \mathrm{mL} \mathrm{MgSO}_{4}\end{array}$ & 7.081 & 7.081 & 5.51 & 239.28 & 7.024 & 7.024 & 5.472 & 233.8 & 0.057 & 0.057 & 0.038 & 5.48 \\
\hline
\end{tabular}

crystallization in noncentrosymmetric fashion, resulting in crystallization of glycine. In general, to inhibit $\gamma$-polymorph of glycine in aqueous solutions, the presence of dimers is to be destroyed. From the literature it is found that the additive magnesium sulfate is polar, ionic and it is soluble in water. Hence, the polar molecule $\mathrm{MgSO}_{4}$ is added to destroy dimers or to prevent the formation of the dimers. At higher additive concentration of magnesium sulfate $\geqslant 2 \mathrm{~g} / \mathrm{mL}$, the $\gamma$-form of glycine crystals is obtained. It was found that the additive molecule suppressed the growth of nucleation of $\alpha$-form of glycine. From the crystal morphology of $\gamma$-glycine (Fig. 7b), it is apparent that the additive molecule $\mathrm{MgSO}_{4}$ has retarded its growth at only one pole of the polar crystal, leaving the crystal free to grow at the opposite pole. This type of behavior is called unidirectional growth behavior which is common in highly polar acentric crystals [22-25]. It is explicit from the schematic drawing of $\gamma$-glycine (Fig. 7b) that one end of the polar axis exposes positively charged protonated amino groups and the other end exposes negatively charged car- boxylate groups. Srinivasan et al. [22-24] and Renuga Devi et al. [25] reported zero growth or unidirectional growth behavior of $\gamma$-glycine along one of the $+c$-axis and cone shaped rough curved non-crystallographic facets at the other end of the c-axis in water-ammonia solutions. In our case, two key results are distinguished from the schematic drawing of $\gamma$-glycine: (i) unidirectional growth behavior along one of the $+\mathrm{c}$-axis of the crystal. (ii) rough trigonal pyramidal shape with non-crystallographic facets at one end of the c-axis which is pointing through the central tip of the crystal and passing normal to the paper. Due to such crystal behavior, the crystal ends up with a truncated tip at the center portion of the crystal and rough trigonal pyramidal shaped non-crystallographic facets at opposite end. This type of anisotropic crystal growth behavior is common for polar acentric crystals as reported in case of $\alpha$-resorcinol and other polar crystal investigations [22-25]. From the solubility curves results, it is suggested that the interaction between magnesium ions and glycine molecules plays a vital role in the nucleation studies of polymorphs 
of glycine. The interaction between magnesium ions and glycine molecules including electrostatic interaction may get stronger when the concentration of $\mathrm{Mg}^{2+}$ ions is higher. Thus, the increase of $\mathrm{Mg}^{2+}$ ions in glycine solutions, which are more favorable for the nucleation and growth of $\gamma$-glycine polymorph, makes the $\gamma$ polymorph more thermodynamically stable than $\alpha$-polymorph.

\subsection{Single crystal X-ray diffraction analysis}

Single crystals of gamma glycine, $0.3 \mathrm{~mm}$ in size, were subjected to single crystal X-ray diffraction analysis using Enraf Nonius CAD 4-MV31 Bruker Kappa Apex II single crystal X-ray diffractometer to identify the unit cell dimensions. $\gamma$-glycine crystallized from aqueous solution doped with $3 \mathrm{~g} / \mathrm{mL}$ of magnesium sulfate was chosen for the XRD study. The computed unit cell dimensions of the gamma glycine crystal were found to be $\mathrm{a}=7.13 \AA, \mathrm{b}=7.13 \AA$, c $=5.55 \AA$, $\alpha=\beta=90^{\circ}, \gamma=120^{\circ}$ and volume $\mathrm{V}=244 \AA^{3}$. Incorporation of some amount of magnesium in the crystal lattice resulted in slight changes in the lattice parameters when compared with the literature values [3, 11]. The grown gamma glycine crystal belongs to hexagonal crystal system with noncentrosymmetric space group $\mathrm{P} 3_{2}$. It is evident that the incorporation of small amount of magnesium in the crystal lattice slightly alters the lattice parameters which has been revealed by single crystal XRD data. The computed unit cell parameters match well with the literature values $[9,11]$.

\subsection{Powder XRD and ICP-OES studies}

The powdered samples of the grown crystals were subjected to powder XRD studies using Bruker AXS D8 advance X-ray powder diffractometer. The powdered samples were scanned from $10^{\circ}$ to $80^{\circ}$ at a scan rate of $1 \% \mathrm{~min}$. Fig. 8 shows the indexed powder XRD patterns of glycine polymorphs crystallized from aqueous solution doped with $1 \mathrm{~g}$ to $8 \mathrm{~g}$ of magnesium sulfate $\left(\mathrm{MgSO}_{4}\right)$ salt. The distinct difference between two polymorphs of glycine is observed in the powder XRD spectra. From the spectra it is evident that the $100 \%$

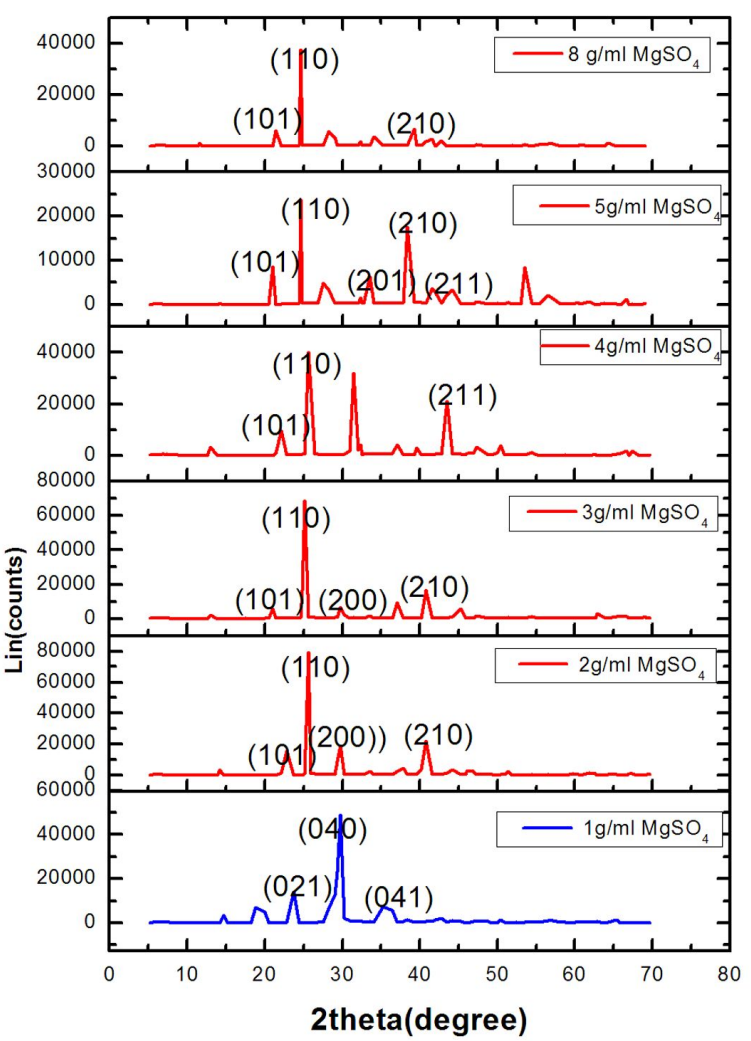

Fig. 8. Indexed powder XRD spectra of glycine polymorphs.

PXRD diffraction peak of $\alpha$-glycine corresponds to $(040)$ plane at an angle $2 \theta \approx 30^{\circ}$, whereas the $\gamma$-polymorph of glycine has its $100 \%$ diffraction peak at $2 \theta \approx 25^{\circ}$ and its corresponding (h k l) plane is $\left(\begin{array}{lll}1 & 1 & 0\end{array}\right)$ plane. The signature peaks of $\alpha$ - and $\gamma$-glycine confirm the existence of glycine in $\alpha$ - and $\gamma$-form. The observed (h k l) planes and $2 \theta$ values of $\alpha$ - and $\gamma$-glycine match well with the literature and JCPDS Card No. 32-1702 and JCPDS Card No. 06-230, respectively [30]. The good crystallinity of the grown crystals was confirmed by the appearance of sharp and strong signature peaks. Table 2 shows the computed lattice parameters obtained by unit cell software program. The computed lattice parameters are in line with the already published results. Small shift in the $100 \%$ peak position of $2 \theta$ values resulting from the addition of magnesium sulfate impurity is noticeable in Table 3 . Inductively coupled plasma optical emission 
spectrometry (ICP-OES) elemental analysis was carried out by using Thermo Electron Iris Intrepid II XSP DUO flexible axial and radial view instrument. The grown crystals were powdered finely and the powdered sample was dissolved in $5 \mathrm{~mL}$ nitric acid and transferred into a $50 \mathrm{~mL}$ flask. The diluted sample was filtered and analyzed using ICP-OES system. Table 4 presents the percentage incorporation of magnesium species in the crystal samples. From the ICP-OES elemental analysis it is concluded that the percentage value of magnesium ranging from $0.035 \%$ to $0.154 \%$ inhibited the growth of gamma phase of glycine, whereas the $0.024 \%$ percentage value of magnesium inhibited the $\alpha$-phase of glycine. Moreover, the obtained percentage value of magnesium is too low to form a complex, so the magnesium element can be incorporated in the void space within the crystal lattice of $\gamma$-glycine.

Table 4. ICP-OES analysis result.

\begin{tabular}{lcc}
\hline \multicolumn{1}{c}{ Sample name } & $\begin{array}{c}\text { Presence of } \\
\text { magnesium } \\
\text { element [\%] }\end{array}$ & $\begin{array}{c}\text { Characteristic } \\
\text { wavelength }\end{array}$ \\
\hline \hline $\begin{array}{l}\text { glycine }+ \\
1 \mathrm{~g} / \mathrm{mL} \mathrm{MgSO}_{4} \\
\text { glycine }+\end{array}$ & 0.024 & \\
$\begin{array}{l}\text { g/mL } \mathrm{MgSO}_{4} \\
\text { glycine }+\end{array}$ & 0.067 & $\begin{array}{l}\text { 285.224 } \mathrm{nm} \text { is } \\
\text { the fingerprint } \\
\text { wavelength of } \\
\text { magnesium } \\
\text { element G.R. }\end{array}$ \\
$\begin{array}{l}3 \mathrm{~g} / \mathrm{mL} \mathrm{MgSO}_{4} \\
\text { glycine }+\end{array}$ & 0.046 & $\begin{array}{c}\text { Dillip et al. [11] } \\
4 \mathrm{~g} / \mathrm{mL} \mathrm{MgSO}_{4} \\
\text { glycine }+\end{array}$ \\
$\begin{array}{l}5 \mathrm{~g} / \mathrm{mL} \mathrm{MgSO}_{4} \\
\text { glycine }+\end{array}$ & 0.038 & 0.035 \\
$\begin{array}{l}6 \mathrm{~g} / \mathrm{mL} \mathrm{MgSO}_{4} \\
\text { glycine }+\end{array}$ & 0.154 & \\
$7 \mathrm{~g} / \mathrm{mL} \mathrm{MgSO}_{4}$ & 0.081 & \\
glycine + & 0.064 & \\
$8 \mathrm{~g} / \mathrm{mL} \mathrm{MgSO}_{4}$ & & \\
\hline
\end{tabular}

\subsection{Interpretation of optical transmit- tance spectrum of $\gamma$-glycine}

The study on transmittance of $\gamma$-glycine crystals in the wavelength of $200 \mathrm{~nm}$ to $800 \mathrm{~nm}$ gave significant information for its suitability in blue/green light applications. The optical transmission range of $\gamma$-glycine crystal and lower cutoff wavelength was computed using Varian, Cary 5000 UV-Vis-NIR spectrophotometer in the wavelength $\lambda$ of $200 \mathrm{~nm}$ to $800 \mathrm{~nm}$. The $\gamma$-glycine crystal optical transmittance spectrum is presented in Fig. 9. The optical transmittance percentage between the wavelength of $200 \mathrm{~nm}$ and $400 \mathrm{~nm}$ was found to be $86 \%$. The higher transmittance percentage $89 \%$ between the wavelength of $500 \mathrm{~nm}$ and $700 \mathrm{~nm}$ implies suitability of $\gamma$-glycine for frequency doubling and photonics applications. The observed lower cutoff wavelength, well below $300 \mathrm{~nm}$ in the UV region, is the important parameter required for frequency doubling and photonics, optoelectronic device applications [10-14].

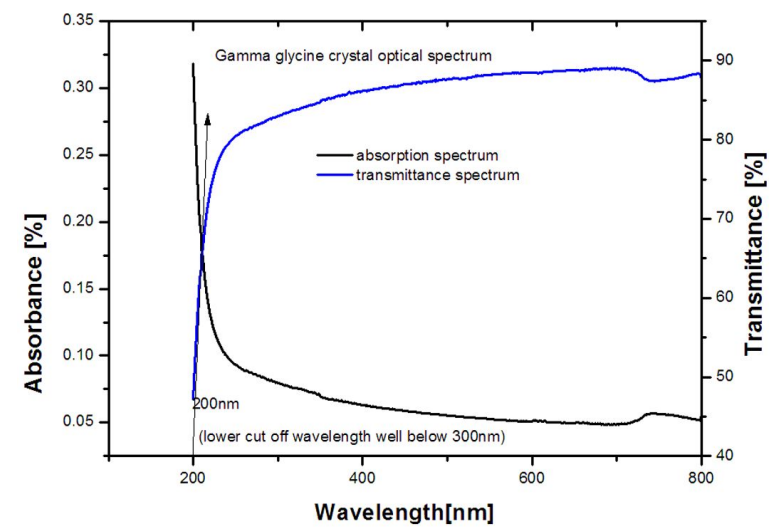

Fig. 9. $\gamma$-glycine optical transmittance and absorption spectra.

\subsection{Kurtz and Perry powder NLO exami- nation}

The nonlinear optical behavior of the powdered gamma glycine crystals was examined using Kurtz et al. powder NLO study [31]. A Q switched high energy Nd:YAG laser (QUANTA RAY Model LAB - 170-10) was used to produce the input light beam of $1064 \mathrm{~nm}$ with a pulse width of $8 \mathrm{~ns}$ at a repetition rate of frequency about $10 \mathrm{~Hz}$ incident normal on the powdered crystalline samples of $\gamma$-glycine crystals. The green light emission from crystalline samples of $\gamma$-glycine $(\lambda=532 \mathrm{~nm})$ confirmed the second harmonic generation behavior and noncentrosymmetric nature of $\gamma$-glycine. The space group of the grown $\gamma$-glycine crystal is $\mathrm{P} 3_{2}$ 
Table 5. NLO testing reports of gamma glycine crystal.

\begin{tabular}{lcccc}
\multicolumn{1}{c}{$\begin{array}{c}\text { Sample used for } \\
\text { NLO measurement }\end{array}$} & $\begin{array}{c}\text { Output energy } \\
{[\mathrm{mJ}]}\end{array}$ & Input energy [J] & SHG efficiency & Instrument \\
\hline \hline $\begin{array}{l}\text { Gamma glycine single } \\
\text { crystals grown from }\end{array}$ & & & & \\
$\begin{array}{l}\text { aqueous solutions doped } \\
\text { with } 3 \mathrm{~g} / \mathrm{mL} \text { of }\end{array}$ & 10.28 & 0.689 & $\begin{array}{c}1.31 \text { times better } \\
\text { than KDP }\end{array}$ & $\begin{array}{c}\text { Q-switched } \\
\text { high energy }\end{array}$ \\
$\begin{array}{l}\text { magnesium sulfate } \\
\text { impurity was taken for }\end{array}$ & & & & $1064 \mathrm{~nm}, 10 \mathrm{~Hz}$ \\
NLO investigation & & & & \\
KDP reference material & 7.8 & 0.689 & & \\
\hline
\end{tabular}

Table 6. Comparison of SHG conversion efficiency output for various solvents

\begin{tabular}{lcc}
\hline $\begin{array}{c}\text { Solvent chosen for inhibiting gamma } \\
\text { phase of glycine }\end{array}$ & SHG conversion efficiency with respect to KDP & Literature \\
\hline \hline water and cesium chloride & 1.72 & {$[28]$} \\
water and lithium bromide & 3 & {$[26]$} \\
water and strontium chloride & 1.06 & {$[27]$} \\
water and phosphoric acid & 1.3 & {$[15]$} \\
water and magnesium chloride & 6 & {$[11]$} \\
water and magnesium sulphate & 1.31 & Present investigation \\
\hline
\end{tabular}

which is noncentrosymmetric space group. This type of NLO crystal is suited as a potential candidate for nonlinear optical and photonics applications. The input energy was $0.689 \mathrm{~J}$ for both crystalline samples of $\gamma$-glycine and a reference material KDP. The output energy of $\gamma$-glycine sample was $10.28 \mathrm{~mJ}$, whereas the reference material KDP gave $7.80 \mathrm{~mJ}$ for the same input energy of $0.689 \mathrm{~J}$. From the NLO test, it is evident that the second harmonic generation efficiency of $\gamma$-glycine sample was better than that of the reference inorganic material KDP. The NLO test report of the gamma glycine powdered sample is presented in Table 5. The comparison of second harmonic generation conversion efficiency of the crystals grown from various solvents is given in Table 6 .

\section{Conclusions}

Glycine crystallization experiments in the presence of magnesium sulfate as impurity salt showed the difference between $\alpha$ - and $\gamma$-polymorphs of glycine. Nucleation time span was measured.
Solubility, crystal habit, $\mathrm{pH}$ of the glycine polymorphs were studied. Optically clear $\alpha$ - and $\gamma$-glycine single crystals were grown by slow solvent evaporation method at room temperature. The incorporation of magnesium species in the grown crystal was measured using ICP-OES analysis. Single crystal X-ray diffractometer study showed that the grown $\gamma$-glycine crystal belongs to hexagonal crystal system with noncentrosymmetric space group $\mathrm{P} 3_{2}$, suitable for nonlinear optical and photonics applications. From the meticulous investigation of glycine polymorphs in $\mathrm{MgSO}_{4}$ solution it may be concluded that the tailor-made impurity magnesium sulfate was not incorporated into the crystal lattice of the grown crystal, which was confirmed by single crystal XRD analysis (i.e. molecular formula of glycine $\mathrm{C}_{2} \mathrm{H}_{5} \mathrm{NO}_{2}$ remained unchanged), but its presence in the aqueous solution inhibited the polymorph $\gamma$-glycine most efficiently. It was confirmed by the analysis of (h k l) planes of the grown glycine polymorphs obtained from the indexed powder XRD diffraction patterns and computed using UNIT CELL software 
package. The computed lattice parameters match well with JCPDS PDF\# 32-1702 and JCPDS PDF\# 06-0230. The powder X-ray diffractogram confirmed that there was no incorporation of additives in the host crystal lattice. $\gamma$-glycine optical transmittance spectrum showed a wide transparency window in the wavelength range of $200 \mathrm{~nm}$ to $800 \mathrm{~nm}$. The second harmonic generation conversion efficiency of the grown $\gamma$-glycine single crystal was about 1.31 times better than that of powdered sample of reference material, i.e. potassium dihydrogen phosphate KDP.

\section{References}

[1] Poornachary S.K., Chow P.S., Tan R.B., Cryst. Growth Des., 8 (2008), 179.

[2] Poornachary S.K., Chow P.S., Tan R.B., J. Cryst. Growth, 310 (2008), 3034.

[3] Litaka Y., Acta Crystallogr., 14 (1961), 1.

[4] LitakA Y., Proc. Japan Acad., 30 (1954), 109.

[5] LiTAKA Y., Acta Crystallogr., 11 (1958), 225.

[6] LitakA Y., Acta Crystallogr., 13 (1960), 35.

[7] Dawson A., Allan D.R., Belmonte S.A., Clark S.J., DAVID W.I.F., MC GREgOR P.A., PARSONS S., Pulham C.R., SAWyer L., Cryst. Growth Des., 5 (2005), 1415.

[8] Boldyreva E.V., Cryst. Eng., 6 (2003), 235.

[9] MARsh R.E., Acta Crystallogr., 11 (1958), 654.

[10] Dillip G.R., Raghavaiah P., Mallikarjuna K., Madhukar Reddy C., Bhagavannarayana G., Ramesh Kumar V., Deva Prasad Raju B., Spectrochim. Acta Part A, 79 (2011), 1123.

[11] Dillip G.R., Bhagavannarayana G., Raghavaiah P., Deva Prasad Raju B., Mater. Chem. Phys., 134 (2012), 371.

[12] Narayanbhat M., Dharmaprakash S.M., $J$. Cryst. Growth, 242 (2002), 245.

[13] Narayana Moolya B., Jayarama A., Suresh Kumar M.R., Dharmaprakash S.M., J. Cryst. Growth, 280 (2005), 581.

[14] Zulifiqar Ali Ahamed S.D., Dillip G.R., Raghavaiah P., Mallikarjuna K., Deva Prasad Raju B., Arab. J. Chem., 6 (2013), 429.

[15] Parimaladevi R., SeKar C., Spectrochim. Acta Part A, 76 (2010), 490.
[16] Anbuchudar Azhagan S., Ganesan S., Optik, 11 (2012), 993.

[17] Anbuchudar Azhagan S., Ganesan S., Optik, 6 (2013), 526.

[18] Anbuchudar Azhagan S., Ganesan S., Optik, 15 (2013), 2251.

[19] Anbu Chudar Azhagan S., Ganesan S., Optik, 20 (2013), 4452.

[20] Anbu Chudar Azhagan S., Ganesan S., Optik, 23 (2013), 6456.

[21] Anbuchudar Azhagan S., Ganesan S., IJPS, 8 (2013), 6.

[22] Srinivasan K., Renuga Devi K., Anbuchudar AzHagan S., Cryst. Res. Technol., 46 (2011), 159.

[23] Srinivasan K., J. Cryst. Growth, 311 (2008), 156.

[24] Srinivasan K., Arumugam J., Opt. Mater., 30 (2007), 40.

[25] Renuga Devi K., SRinivasan K., Cryst. Res. Technol., 50 (2015), 389.

[26] BALAKRISHNAN T., RAMESH BABU R., RAMAMURThi K., Spectrochim. Acta Part A, 69 (2008), 1114.

[27] Anbuchezhiyan M., Ponnusamy S., Singh S. P., Pal P.K., Datta P.K., Muthamizhchelvan C., Cryst. Res. Technol., 45 (2010), 497.

[28] Yogambal C., Ezhil Vizhi R., Rajan Babu D., Cryst. Res. Technol., 50 (2015), 22.

[29] Sekar C., Parimaladevi R., Spectrochim. Acta Part A, 74 (2009), 1160.

[30] Organic Index to the Powder Diffraction File, Joint committee of Powder Diffraction standards, 2002.

[31] Kurtz S.K., Perry T.T., J. Appl. Phys., 39 (1968), 3798.

[32] He G., Bhamidi V., Wilson S.R., Tan R.B.H., Kenis P.J.A., Zukoski C.F., Cryst. Growth Des., 6 (2006), 1746.

[33] Towler C.S., Davey R.J., Lancaster R.W., Price C.J., J. Am. Chem. Soc., 126 (2004), 13347.

[34] Li L., Lechuga-Ballesteros D., SzKudlareK B.A., NAIR Rodriguez-Hornedo N., J. Colloid. Interf. Sci., 168 (1994), 8.

[35] Bisker-Leib V., Doherty M.F., Cryst. Growth Des., 3 (2002), 221.
Received 2017-09-25

Accepted 2018-07-14 